\title{
Actual evapotranspiration of subalpine meadows in the Qilian Mountains, Northwest China
}

\author{
GAO Yunfei ${ }^{1}$, ZHAO Chuanyan ${ }^{2 *}$, Muhammad W ASHIQ ${ }^{3}$, WANG Qingtao ${ }^{1}$, RONG \\ Zhanlei $^{1}$, LIU Junjie ${ }^{1}$, MAO Yahua ${ }^{2}$, GUO Zhaoxia ${ }^{2}$, WANG Wenbin ${ }^{1}$ \\ ${ }^{1}$ State Key Laboratory of Grassland and Agro-Ecosystems, School of Life Sciences, Lanzhou University, Lanzhou 730000, \\ China; \\ ${ }^{2}$ State Key Laboratory of Grassland and Agro-Ecosystems, College of Pastoral Agriculture Science and Technology, Lanzhou \\ University, Lanzhou 730000, China; \\ ${ }^{3}$ Ministry of Natural Resources and Forestry, Timmins District, 5520 Hwy 101 E, South Porcupine, ON, P0N1H0, Canada
}

\begin{abstract}
As a main component in water balance, evapotranspiration (ET) is of great importance for water saving, especially in arid and semi-arid areas. In this study, the FAO (Food and Agriculture Organization) Penman-Monteith model was used to estimate the magnitude and temporal dynamics of reference evapotranspiration $\left(\mathrm{ET}_{0}\right)$ in 2014 in subalpine meadows of the Qilian Mountains, Northwest China. Meanwhile, actual ET $\left(\mathrm{ET}_{\mathrm{c}}\right)$ was also investigated by the eddy covariance (EC) system. Results indicated that $\mathrm{ET}_{\mathrm{c}}$ estimated by the EC System was $583 \mathrm{~mm}$, lower than $\mathrm{ET}_{0}(923 \mathrm{~mm})$ estimated by the FAO Penman-Monteith model in 2014. Moreover, ET $\mathrm{E}_{0}$ began to increase in March and reached the peak value in August and then declined in September, however, $\mathrm{ET}_{\mathrm{c}}$ began to increase from April and reached the peak value in July, and then declined in August. Total $\mathrm{ET}_{\mathrm{c}}$ and $\mathrm{ET}_{0}$ values during the growing season (from May to September) were 441 and $666 \mathrm{~mm}$, respectively, which accounted for $75.73 \%$ of annual cumulative $\mathrm{ET}_{\mathrm{c}}$ and $72.34 \%$ of annual cumulative $\mathrm{ET}_{0}$, respectively. A crop coefficient $\left(k_{\mathrm{c}}\right)$ was also estimated for calculating the $\mathrm{ET}_{\mathrm{c}}$, and average value of $k_{\mathrm{c}}$ during the growing season was 0.81 (ranging from 0.45 to 1.16$)$. Air temperature $\left(T_{\mathrm{a}}\right)$, wind speed $(u)$, net radiation $\left(R_{\mathrm{n}}\right)$ and soil temperature $\left(T_{\mathrm{s}}\right)$ at the depth of $5 \mathrm{~cm}$ and aboveground biomass were critical factors for affecting $k_{\mathrm{c}}$, furthermore, a daily empirical $k_{c}$ equation including these main driving factors was developed. Our result demonstrated that the $\mathrm{ET}_{\mathrm{c}}$ value estimated by the data of $k_{\mathrm{c}}$ and $\mathrm{ET}_{0}$ was validated and consistent with the growing season data in 2015 and 2016.
\end{abstract}

Keywords: actual evapotranspiration; reference evapotranspiration; crop coefficient; meteorological factors; biotic factors

Citation: GAO Yunfei, ZHAO Chuanyan, Muhammad W ASHIQ, WANG Qingtao, RONG Zhanlei, LIU Junjie, MAO Yahua, GUO Zhaoxia, WANG Wenbin. 2019. Actual evapotranspiration of subalpine meadows in the Qilian Mountains, Northwest China. Journal of Arid Land, 11(3): 371-384. https://doi.org/10.1007/s40333-019-0012-y

\section{Introduction}

Water balance strongly influences the structure, function, and productivity of terrestrial ecosystems (Burman and Pochop, 1994). A critical component of water balance is actual evapotranspiration (ET $\mathrm{ET}_{\mathrm{c}}$ ) (Mitchell et al., 2009; Valipour et al., 2017), and determination of water balance depends on precise estimation of $\mathrm{ET}_{\mathrm{c}}$ (Jensen et al., 1990; Allen et al., 1994; Jensen et al.,

\footnotetext{
"Corresponding author: ZHAO Chuanyan (E-mail: nanzhr@1zb.ac.cn)

Received 2017-10-31; revised 2018-07-28; accepted 2018-08-28

C Xinjiang Institute of Ecology and Geography, Chinese Academy of Sciences, Science Press and Springer-Verlag GmbH Germany, part of Springer Nature 2019
} 
1997; Allen et al., 1998; ASCE-EWRI, 2005; Veroustraete et al., 2008; Allen et al., 2011; Semalty et al., 2011; Hssaine et al., 2018). Understanding of $E_{\mathrm{c}}$ is also important for water utilization and management, especially in arid and semi-arid regions (Li et al., 2014; Zhao and Zhao, 2014). Qilian Mountains, located in Northwest China, are water sources for many inland rivers in Hexi Corridor. Subalpine meadows (grasslands) are a major land use in these mountains where heavy grazing not only impacts grass growth conditions but also affects ET. Therefore, it is imperative to estimate $\mathrm{ET}_{\mathrm{c}}$ of these alpine meadows with consideration of grazing impact on $\mathrm{ET}_{\mathrm{c}}$.

A number of methods and models have been developed and used to estimate $\mathrm{ET}_{\mathrm{c}}$ such as Bowen (Ohmura, 1982; Sun et al., 2006; Fang et al., 2018), Lysimeter (Howell et al., 1991; Gao et al., 2015), eddy covariance (EC) (Swinbank, 1951; Massman, 2000), water balance (Mastrorilli et al., 1998; Saadi et al., 2018) and FAO (Food and Agriculture Organization) Penman-Monteith (P-M) model (Allen et al., 1998). This study focused on two methods: EC and FAO Penman-Monteith model. The EC is a micro-meteorological approach widely used to study $\mathrm{ET}_{\mathrm{c}}$ at the ecosystem level (Massman, 2000; Falge et al., 2001; Aubinet et al., 2012). The FAO Penman-Monteith model is a modified version of P-M model (Monteith, 1965) recommended by the FAO to estimate $\mathrm{ET}_{\mathrm{c}}$ for various land uses including grassland (Allen et al., 1998). For each land use, $\mathrm{ET}_{\mathrm{c}}$ is estimated using reference evapotranspiration $\left(\mathrm{ET}_{0}\right)$ values which in turn depend on land use specific crop coefficient $\left(k_{\mathrm{c}}\right)$ (Allen et al., 1998; Yang et al., 2013; Khoshravesh et al., 2017). The $k_{\mathrm{c}}$ values, for a specific land use, are generally assigned by the growth stage of the plants species. For example, the $k_{\mathrm{c}}$ values of $0.40,1.05$, and 0.85 in grasslands are respectively reported for initial-, middle-, and late-season growth stages of grass (Allen et al., 1998). Studies also show that some additional factors, such as meteorological data and vegetation biomass, also affect $k_{\mathrm{c}}$ value (Lockwood, 1999; Williams and Ayars, 2005; Zhou and Zhou, 2009; Yang and Zhou, 2011; Zhang et al., 2012). Therefore, accurately calculating $k_{\mathrm{c}}$ can provide more reliable estimation of $\mathrm{ET}_{\mathrm{c}}$.

$\mathrm{The}_{\mathrm{E}}$ for subalpine meadows in the Qilian Mountains has been estimated (ranging from 2.88 to $3.26 \mathrm{~mm} / \mathrm{d}$ ) using micro-lysimeter method (Song et al., 2004; Yang et al., 2013). However, the $\mathrm{ET}_{\mathrm{c}}$ estimation by micro-lysimeter is influenced by the weather conditions, i.e., it might be over-estimated during sunny days and under-estimated during rainy weather (Zhang et al., 2012; Zhou and Zhou, 2009). Thus, it is unsuitable for long-term ET $_{c}$ estimation during all weather conditions. To fill this knowledge gap for grasslands in the Qilian Mountains, we used (1) EC system to observe $\mathrm{ET}_{\mathrm{c}}$ at daily time scale, and (2) FAO Penman-Monteith model to estimate $\mathrm{ET}_{0}$. The objectives of this study are (1) to estimate $\mathrm{ET}_{\mathrm{c}}$ based on $k_{\mathrm{c}}$ and $\mathrm{ET}_{0}$ values of the subalpine grasslands in the Qilian Mountains, and (2) to develop and validate a model of $k_{\mathrm{c}}$ based on meteorological factors and vegetation biomass of subalpine grasslands in the Qilian Mountains.

\section{Materials and methods}

\subsection{Study area}

The study area is located in Tianlaochi Catchment in the upper reaches of the Heihe River $\left(38^{\circ} 23^{\prime} 56^{\prime \prime}-38^{\circ} 26^{\prime} 47^{\prime \prime} \mathrm{N}, 99^{\circ} 53^{\prime} 57^{\prime \prime}-99^{\circ} 57^{\prime} 10^{\prime \prime} \mathrm{E}\right)$ with the elevation ranging from 2660 to $4400 \mathrm{~m}$ a.s.l. (Fig. 1). Experimental site for this study is located at $3070 \mathrm{~m}$ altitude in subalpine meadow in the Qilian Mountains. The study area belongs to a typical alpine semi-arid climate, characterized by long and cold winters, and short and warm summers. The mean annual precipitation is about $435.0( \pm 5.6) \mathrm{mm}$ with $84.2 \%$ precipitation occurring during May to September. The annual mean temperature is about $-0.6^{\circ} \mathrm{C}-2.0^{\circ} \mathrm{C}$, and mean January and mean July temperatures are $-13.1^{\circ} \mathrm{C}$ and $12.1^{\circ} \mathrm{C}$, respectively. The soil type is mountain grey cinnamon with up to $50 \mathrm{~cm}$ depth and gravel below $50 \mathrm{~cm}$. Vegetation community mostly belongs to annual grasses, i.e., Elymusnutans griseb and Foeniculum vulgare, and their roots grow up to $30 \mathrm{~cm}$.

\subsection{Data collection}

\subsubsection{Meteorological and soil physical data}

At the study site, a weather station and an EC system were set up in 2011 and 2013, respectively. Table 1 shows the list of meteorological factors for which data are being collected at half an hour intervals and soil physical data at the study site. 


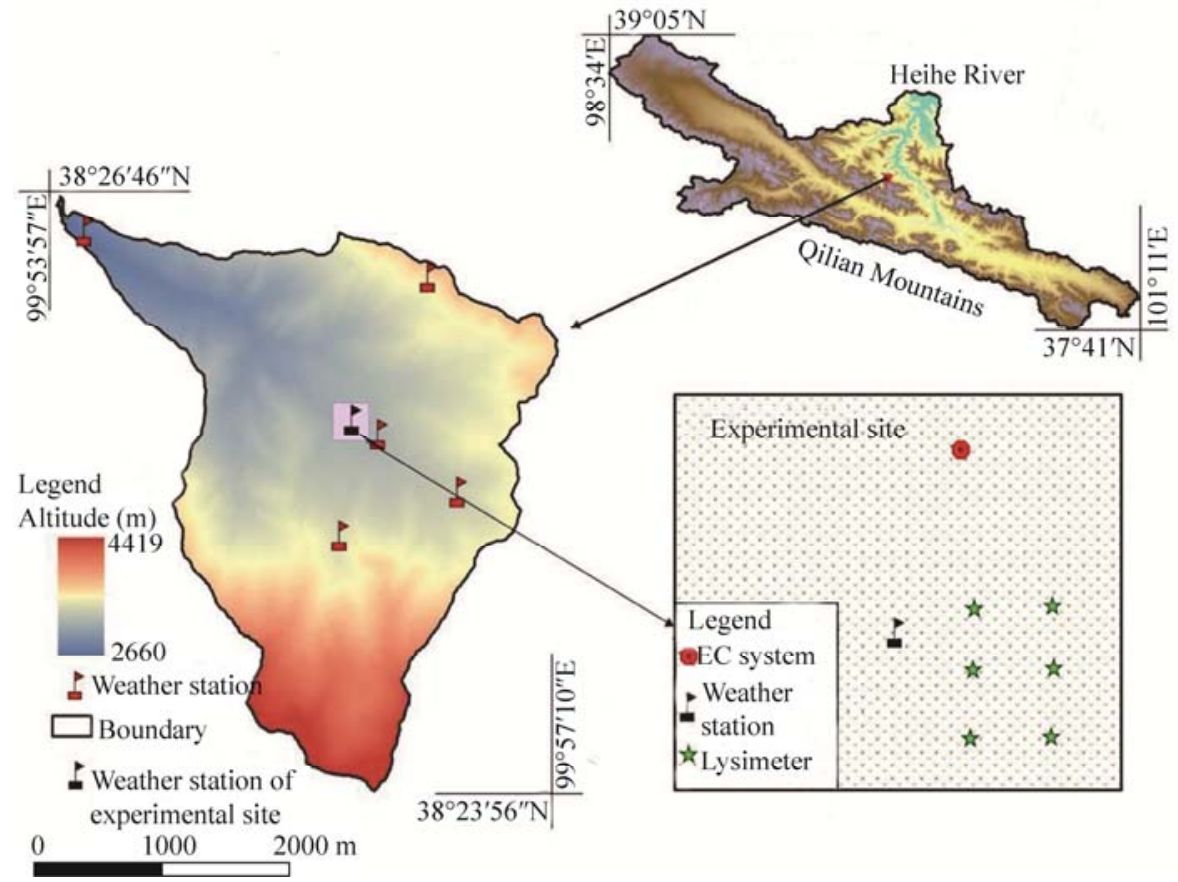

Fig. 1 Geographic location of the study area and distribution of observation instruments in the experimental site. EC, eddy covariance.

Table 1 Summary of the meteorological and soil physical data observed at the weather station

\begin{tabular}{|c|c|c|c|c|}
\hline Parameter & Company & Country & Observational elevation & Abbreviation \\
\hline Net radiation & Gene & USA & $2 \mathrm{~m}$ & $R_{\mathrm{n}}$ \\
\hline Short wave radiation & Gene & USA & $2 \mathrm{~m}$ & $R_{\mathrm{s}}$ \\
\hline Soil heat flux & Gene & USA & $-5 \mathrm{~cm}$ & $G$ \\
\hline Wind speed & Hobo & USA & $2 \mathrm{~m}$ & $u$ \\
\hline Air temperature & Hobo & USA & $2 \mathrm{~m}$ & $T_{\mathrm{a}}$ \\
\hline Relative humidity & Hobo & USA & $2 \mathrm{~m}$ & RH \\
\hline Pressure & Hobo & USA & $2 \mathrm{~m}$ & $P_{\mathrm{a}}$ \\
\hline Precipitation & Hobo & USA & $1.8 \mathrm{~m}$ & $P$ \\
\hline Soil temperature & Decagon & USA & $-5,-10,-20$, and $-50 \mathrm{~cm}$ & $T_{\mathrm{s} 5}, T_{\mathrm{s} 10}, T_{\mathrm{s} 20}$, and $T_{\mathrm{s} 50}$ \\
\hline Soil water content & Decagon & USA & $-5,-10,-20$, and $-50 \mathrm{~cm}$ & $\mathrm{SWC}_{5}, \mathrm{SWC}_{10}, \mathrm{SWC}_{20}$, and $\mathrm{SWC}_{50}$ \\
\hline
\end{tabular}

\subsubsection{Flux measurements}

The EC system was used to measure $\mathrm{CO}_{2}$ fluxes, sensible heat $(H)$, and latent heat $(L E)$ at $2.2 \mathrm{~m}$ above the ground surface from 2013. $\mathrm{A} \mathrm{CO}_{2} / \mathrm{H}_{2} \mathrm{O}$ infrared analyzer (Li-7550; LI-COR, Inc., Lincoln, NE, USA) and a three-dimensional supersonic anemometer (CSAT-3; Campbell Scientific, Inc., UT, USA) were mounted on a horizontal bar extending from a tower. The $\mathrm{CO}_{2} / \mathrm{H}_{2} \mathrm{O}$ sensor was installed in down-wind direction of supersonic anemometers. The $\mathrm{CO}_{2} / \mathrm{H}_{2} \mathrm{O}$ analyzer was calibrated after every six months. Short wave radiation $\left(R_{\mathrm{s}}\right)$ from the sky and long wave radiation $\left(R_{1}\right)$ from the land surface were measured with a net radiometer (CNR-1; Kipp and Zonen, Delft, The Netherlands) at $1.5 \mathrm{~m}$ above the ground surface. The net radiation $\left(R_{\mathrm{n}}\right)$ was calculated from the difference of $R_{\mathrm{s}}$ and $R_{\mathrm{l}}$. Soil heat fluxes $(G)$ were recorded by a net radiometer at $10 \mathrm{~cm}$ soil depth. The $R_{\mathrm{n}}$ was partitioned into $H, L E$, and $G$.

The energy balance ratio $(r)$ was calculated using the following equation (Gu et al., 1999):

$$
\left.r=\left(\sum(L E+H)\right) /\left(\sum R_{\mathrm{n}}-G\right)\right) \text {. }
$$

The item $L E+H$ measured by the EC system seemed to be underestimated since the average 
value of $r$ was about 0.75 for the entire observation period from 2014 to 2016, which fell in the median region of reported energy closures (0.55-0.99) (Wilson et al., 2002). The lack of energy balance closure had also been reported by Stannard et al., (1994) and Aubinet et al. (2012), and energy balance closure had become accepted as an important new test of EC (Anderson et al., 1984; Mahrt, 1998). We were not trying to specify a particular cause for the imbalance because several possibilities may be involved in the lack of energy closure (Wilson et al., 2002).

In long-term field measurements, gaps in data are a known issue. The gaps in data occur either due to non-recording (instrument malfunction/power failure) or rejection of certain data that do not meet quality control requirements. The quality of flux data collected for this study was assessed through a widely adopted flag system (Mauder and Foken, 2004), which lead to discard some data recorded at night time. The data gap filling was therefore, performed using a lookup table approach that considered both covariation of fluxes with meteorological variables and the temporal autocorrelation of the fluxes (Falge et al., 2001; Reichstein et al., 2005).

\subsubsection{Biotic data}

At the experimental site, six quadrats $(0.5 \mathrm{~m} \times 0.5 \mathrm{~m})$ were randomly selected to collect aboveground biomass. Biomass was measured every three days by cutting the plants at ground level and loading the plants into sampling bags during the growing season (May-October). Each sample was numbered and dried at $65^{\circ} \mathrm{C}$ until a constant weight was obtained.

\subsection{Methods}

\subsubsection{FAO Penman-Monteith model}

The FAO Penman-Monteith model (Allen et al., 1998) was used to calculate $\mathrm{ET}_{0}$, which is expressed as follows:

$$
\begin{gathered}
\mathrm{ET}_{0}=\frac{1}{\lambda}\left(\frac{\Delta}{\Delta+\gamma^{*}}\right)\left(R_{\mathrm{n}}-G\right)+\frac{\gamma}{\gamma^{*}+\Delta}\left(\frac{900}{T+275}\right) u D, \\
\mathrm{ET}_{\mathrm{cm}}=k_{\mathrm{c}} \mathrm{ET}_{0}, \\
\gamma^{*}=\gamma(1+0.33 u),
\end{gathered}
$$

where $\lambda$ is the water latent heat of vaporization $(\mathrm{MJ} / \mathrm{kg}) ; \Delta$ is the slope of the vapor pressure versus temperature curve $\left(\mathrm{kPa} /{ }^{\circ} \mathrm{C}\right) ; R_{n}$ is the net radiation $\left(\mathrm{MJ} /\left(\mathrm{m}^{2} \cdot \mathrm{d}\right)\right) ; G$ is the soil heat flux $\left(\mathrm{MJ} /\left(\mathrm{m}^{2} \cdot \mathrm{d}\right)\right) ; \gamma$ is the psychrometric constant $\left(\mathrm{kPa} /{ }^{\circ} \mathrm{C}\right) ; T$ is the daily mean temperature at $2 \mathrm{~m}$ above the ground surface $\left({ }^{\circ} \mathrm{C}\right) ; u$ is the wind speed at $2 \mathrm{~m}$ above the ground surface $(\mathrm{m} / \mathrm{s}) ; D$ is the vapor pressure deficit $(\mathrm{kPa}) ; \mathrm{ET}_{\mathrm{cm}}$ is the estimated actual evapotranspiration $(\mathrm{mm} / \mathrm{d})$ using the FAO-P-M model; and $k_{\mathrm{c}}$ is the crop coefficient.

\subsubsection{EC model}

EC model was used to calculate the $\mathrm{ET}_{\mathrm{c}}$ :

$$
\mathrm{ET}_{\mathrm{c}}=1000 L E / \lambda \rho_{w}
$$

where $L E$ is the latent heat flux $\left(\mathrm{MJ} /\left(\mathrm{m}^{2} \cdot \mathrm{d}\right)\right) ; \lambda$ is the water latent heat of vaporization $(\mathrm{MJ} / \mathrm{kg})$; and $\rho_{w}$ is the water density $\left(\mathrm{kg} / \mathrm{m}^{3}\right)$.

\subsubsection{Crop coefficient $\left(k_{\mathrm{c}}\right)$}

The daily $k_{\mathrm{c}}$ was obtained by dividing $\mathrm{ET}_{\mathrm{c}}$ values with $\mathrm{ET}_{0}$ values for the year 2014 . The obtained $k_{\mathrm{c}}$ was used to develop two models: one with meteorological factors only, and the other using both meteorological factors and biotic factors. Both models were developed using the data of 2014, and validated using the data of 2015 and 2016.

\subsubsection{Evaluation methods}

In the study, the linear correlation coefficient $\left(R^{2}\right)$, slope, Relative Root-Mean-Squared Error (RRMSE), Coefficient of Determination (CD) and Index of Agreement (IA) were used to examine the extent of the differences between the calculated and observed values of $\mathrm{ET}_{\mathrm{c}}$. The slope was the relative between the straight line and horizontal axis. The $R^{2}$ value was used to assess the correlation between the prediction results with actual situation (Gao et al., 2013). The RRMSE was a measure of relative magnitude of residuals; and the models with smaller RRMSE value are desirable (Gao et al., 2015). The IA was a measure to evaluate the correlation between the 
observed and simulated values, and IA values closer to 1 are desirable ( $\mathrm{Li}$ et al., 2014). The CD was used to measure dispersion of simulated values from the mean observed values, and CD greater than 0.8 indicates that the result was acceptable (Cai et al., 2007). The $R^{2}$ and slope were calculated in Sigmaplot 11.0 (Alexandris and Kerkides, 2003; Yang and Zhou, 2011). The mathematical expressions of RRMSE, CD, and IA were presented as follows:

$$
\begin{gathered}
\mathrm{RRMSE}=\sqrt{\frac{\sum_{i=1}^{\mathrm{n}}\left(O_{i}-E_{i}\right)^{2}}{n}} \times \frac{1}{\bar{O}^{2}}, \\
\mathrm{CD}=\frac{\sum_{i=1}^{n}\left(O_{i}-\bar{O}\right)^{2}}{\sum_{i=1}^{n}\left(E_{i}-\bar{O}\right)^{2}}, \\
\mathrm{IA}=1-\frac{\sum_{i=1}^{n}\left(E_{i}-O_{i}\right)^{2}}{\sum_{i=1}^{n}\left(\left|E_{i}-\bar{O}\right|+\left|O_{i}-\bar{O}\right|\right)^{2}},
\end{gathered}
$$

where $O_{i}$ is the observed value; $\bar{O}$ is the mean observed value; $E_{i}$ is the simulated value; and $n$ is the number of samples.

\subsubsection{Vapor pressure deficit (VPD)}

VPD is the difference between the pressure of water vapor held in saturated air at a given temperature and the pressure of water vapor that exists in the ambient air. It is calculated as follows:

$$
\mathrm{VPD}=0.61008 \times \mathrm{e}^{\frac{17.27 \times T}{T+237.3}} \times\left(1-\frac{\mathrm{RH}}{100}\right),
$$

where $T$ is the daily mean temperature at $2 \mathrm{~m}$ above the ground surface $\left({ }^{\circ} \mathrm{C}\right)$; $\mathrm{RH}$ is the relative humidity.

\section{Results}

\subsection{Variations of meteorological and soil physical factors}

Temporal variations in meteorological factors are shown in Figures 2 and 3. The mean daily values of $R_{\mathrm{n}}, R_{\mathrm{s}}, T_{\mathrm{a}}, \mathrm{VPD}$, and $u$ were $12.43 \mathrm{MJ} /\left(\mathrm{m}^{2} \cdot \mathrm{d}\right), 22.40 \mathrm{MJ} /\left(\mathrm{m}^{2} \cdot \mathrm{d}\right),-0.57^{\circ} \mathrm{C}, 0.658 \mathrm{kPa}$ and $1.21 \mathrm{~m} / \mathrm{s}$, respectively. During the growing season, the sequence of $\mathrm{SWC}$ was $\mathrm{SWC}_{20}>\mathrm{SWC}_{5}>\mathrm{SWC}_{10}>\mathrm{SWC}_{50}$ and that of $T_{\mathrm{s}}$ (soil temperature) was $T_{\mathrm{s} 5}>T_{\mathrm{s} 10}>T_{\mathrm{s} 20}>T_{\mathrm{s} 50}$. Both $T_{\mathrm{a}}$ and $R_{\mathrm{n}}$ reached the minimum in December and the maximum in July. VPD reached the maximum of about $1.180 \mathrm{kPa}$ during the growing season, whereas $u$ reached the maximum in February and the minimum in July.

\subsection{Monthly variations of $\mathbf{E T}_{\mathbf{0}}$ and $\mathrm{ET}_{\mathrm{c}}$}

Figure 4a shows that annual $\mathrm{ET}_{0}$ was $923 \mathrm{~mm}$, which was higher than the annual $\mathrm{ET}_{\mathrm{c}}(583 \mathrm{~mm})$ in 2014. $\mathrm{ET}_{0}$ gradually increased from January and reached the peak value in August and then declined in September. Whereas, $\mathrm{ET}_{\mathrm{c}}$ began to greatly increase in April and reached the peak level in July and then it started to decline in August. The total $\mathrm{ET}_{\mathrm{c}}$ and $\mathrm{ET}_{0}$ values during the growing season (from May to September) were 441 and $666 \mathrm{~mm}$, respectively, which accounted for $75.73 \%$ and $72.34 \%$ of annual $\mathrm{ET}_{\mathrm{c}}$ and $\mathrm{ET}_{0}$, respectively.

Figure $4 \mathrm{~b}$ compares the temporal variation of $\mathrm{ET}_{\mathrm{c}}$ and precipitation $(P)$. The annual values of $\mathrm{ET}_{\mathrm{c}}$ and $P$ were 583 and $546 \mathrm{~mm}$, respectively. The annual ratio of $\mathrm{ET}_{\mathrm{c}}$ to $P$ is 1.067 . However, the values of $\mathrm{ET}_{\mathrm{c}}$ and $P$ during the growing season (from May to September) were 441 and 540 $\mathrm{mm}$, respectively, and the ratio was 0.818 .

\subsection{Temporal variations of $\boldsymbol{k}_{\mathrm{c}}$}

As shown in Figure 5, $k_{\mathrm{c}}$ quickly increased from May to June, and remained a high level in July and August. It declined in September and was about 0.2 at the end of October. During the growing season, $k_{\mathrm{c}}$ exhibited a mean value of 0.81 and fluctuated within the ranges of $0.45-1.16$. 

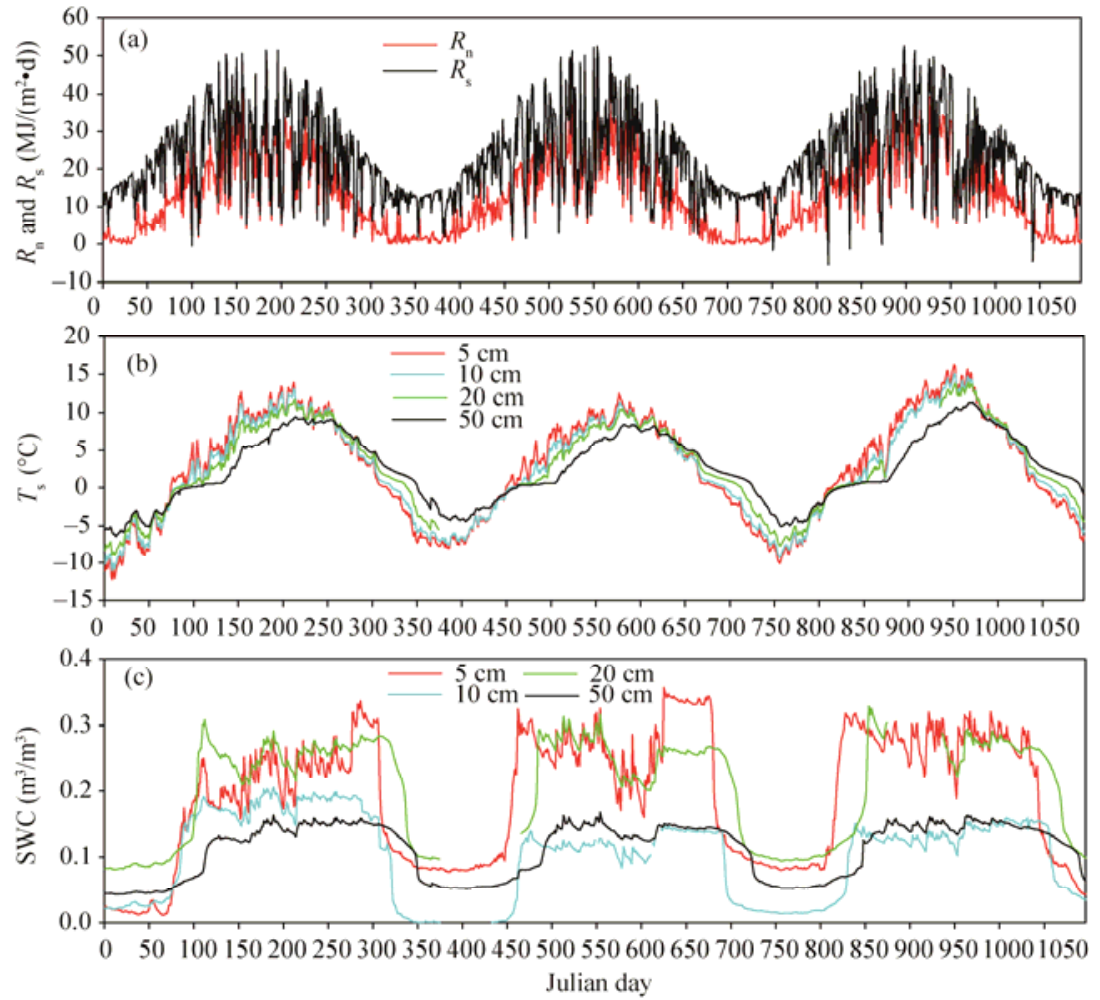

Fig. 2 Temporal variations of meteorological and soil physical factors from 2014 to 2016 . (a) net radiation $\left(R_{\mathrm{n}}\right)$ and short wave radiation $\left(R_{\mathrm{s}}\right)$; (b) soil temperature $\left(T_{\mathrm{s}}\right)$ at the depths of $5,10,20$, and $50 \mathrm{~cm}$ (i.e., $T_{\mathrm{s} 5}, T_{\mathrm{s} 10}, T_{\mathrm{s} 20}$ and $T_{\mathrm{s} 50}$, respectively); (c) soil water content (SWC) at the depths of 5, 10, 20, and $50 \mathrm{~cm}$ (i.e., $\mathrm{SWC}_{5}, \mathrm{SWC}_{10}, \mathrm{SWC}_{20}$ and $\mathrm{SWC}_{50}$, respectively).
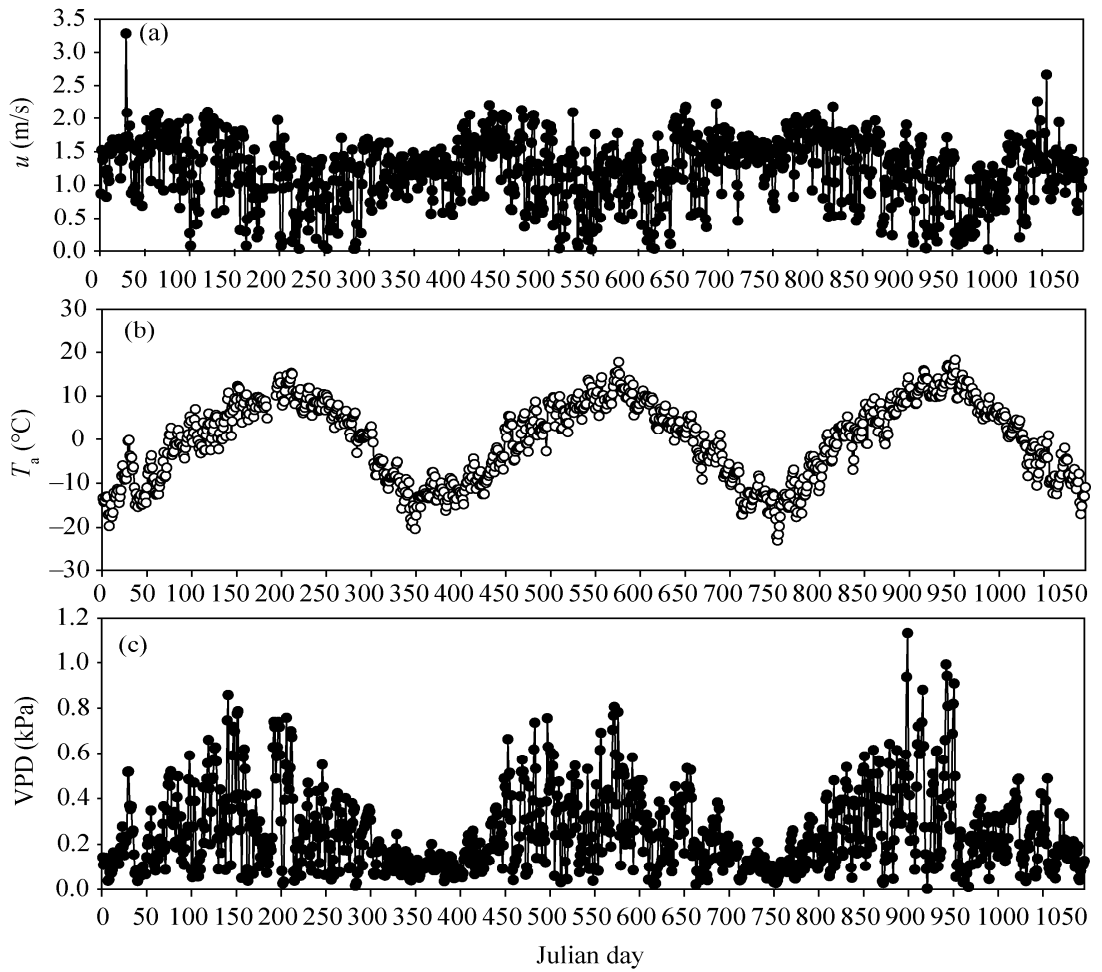

Fig. 3 Temporal variations of meteorological factors from 2014 to 2016. (a) mean wind speed $(u)$ at the 2-m height; (b) air temperature $\left(T_{\mathrm{a}}\right)$; (c) vapor pressure deficit (VPD). 

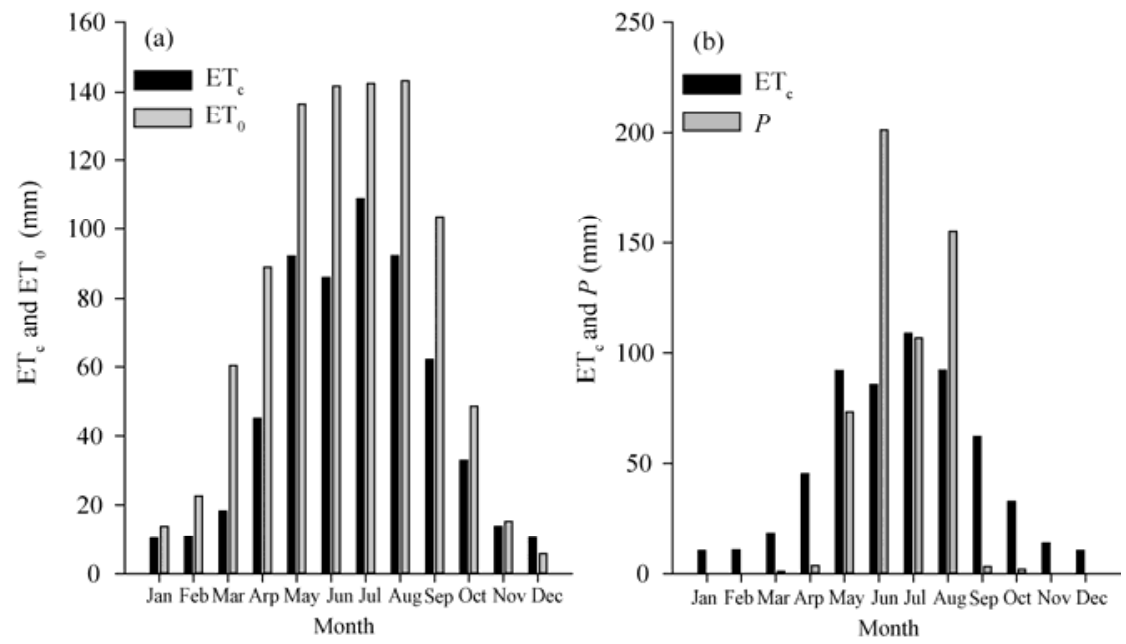

Fig. 4 Annual variations in actual evapotranspiration $\left(E T_{c}\right)$ and reference evapotranspiration $\left(E T_{0}\right)$. (a) annual variations in actual evapotranspiration and (b) precipitation $(P)$.

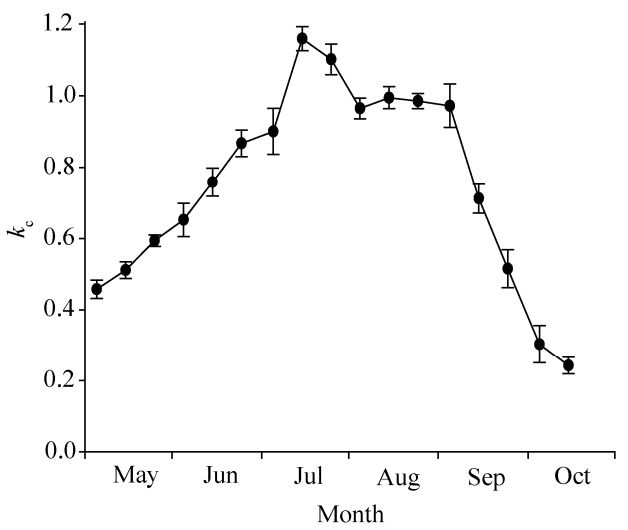

Fig. 5 Variation of crop coefficient $\left(k_{\mathrm{c}}\right)$ at 10-d intervals in 2014. Bars indicate standard errors.

\subsection{Factors impacting $\boldsymbol{k}_{\mathrm{c}}$}

\subsubsection{Effect of environmental factors on $k_{\mathrm{c}}$}

In the study, the Pearson's product-moment correlation coefficients between $k_{\mathrm{c}}$ and environmental factors were computed at a daily scale (Table 2$)$. The significant correlations $(P<0.01)$ of $k_{\mathrm{c}}$ with $u$, $T_{\mathrm{a}}, R_{\mathrm{n}}$ and $T_{\mathrm{s} 5}$ suggest that these factors are critical for controlling $k_{\mathrm{c}}$. The relationships of $k_{\mathrm{c}}$ with $P, \mathrm{SWC}_{5}, T_{\mathrm{s} 10}$ and $T_{\mathrm{s} 20}$ were also significant $(P<0.05)$.

The significant negative correlation between $u$ and RH (Table 2) suggests the role of wind in the blowing away water vapours. The SWCs mainly come from precipitation, i.e., the infiltration into soil layer through rainfall, so there are good correlations between precipitation and SWC. Solar radiation provides energy to soil that in turn increases soil temperature. Using significant climatic factors (Table 2), we developed the following regression model to estimate daily $k_{\mathrm{c}}$ :

$$
\begin{aligned}
k_{\mathrm{c}}= & 0.650+0.224 u-0.038 T_{\mathrm{a}}-0.030 R_{\mathrm{n}}-0.002 P+0.570 \mathrm{SWC}_{5} \\
& +0.110 T_{\mathrm{s} 5}-0.016 T_{\mathrm{s} 10}-0.009 T_{\mathrm{s} 20} .
\end{aligned}
$$

According to Equations 3 and 9, we calculated the daily $\mathrm{ET}_{\mathrm{cmod} 1}$ as follows:

$$
\begin{aligned}
\mathrm{ET}_{\text {cmod1 } 1}= & k_{\mathrm{c}} \times \mathrm{ET}_{0}=\left(0.650+0.224 u-0.038 T_{\mathrm{a}}-0.030 R_{\mathrm{n}}-0.002 P+0.570 \mathrm{SWC}_{5}\right. \\
& \left.+0.110 T_{\mathrm{s} 5}-0.016 T_{\mathrm{s} 10}-0.009 T_{\mathrm{s} 20}\right) \times \mathrm{ET}_{0},
\end{aligned}
$$

where $\mathrm{ET}_{\mathrm{cmod} 1}$ is the $\mathrm{ET}_{\mathrm{c}}$ calculated by Equation 11 . 
Table 2 Pearson's product-moment correlation coefficients between daily crop coefficient $\left(k_{\mathrm{c}}\right)$ and meteorological and soil physical factors, i.e., wind speed $(u)$, air temperature $\left(T_{\mathrm{a}}\right)$, relative humidity $(\mathrm{RH})$, net radiation $\left(R_{\mathrm{n}}\right)$, air pressure $\left(P_{\mathrm{a}}\right)$, precipitation $(P)$, soil water content $(\mathrm{SWC})$ at the depths of $5,10,20$ and $50 \mathrm{~cm}$, and soil temperature $\left(T_{\mathrm{s}}\right)$ at the depths of $5,10,20$ and $50 \mathrm{~cm}$ during the growing season in 2014

\begin{tabular}{|c|c|c|c|c|c|c|c|c|c|c|c|c|c|c|c|}
\hline & $k_{\mathrm{c}}$ & $u$ & $T_{\mathrm{a}}$ & $\mathrm{RH}$ & $R_{\mathrm{n}}$ & $P_{\mathrm{a}}$ & $P$ & $\mathrm{SWC}_{5}$ & $\mathrm{SWC}_{10}$ & $\mathrm{SWC}_{20}$ & $\mathrm{SWC}_{50}$ & $T_{\mathrm{s} 5}$ & $T_{\mathrm{s} 10}$ & $T_{\mathrm{s} 20}$ & $T_{\mathrm{s} 50}$ \\
\hline$k_{\mathrm{c}}$ & 1.000 & & & & & & & & & & & & & & \\
\hline$u$ & $0.194^{* *}$ & 1.000 & & & & & & & & & & & & & \\
\hline$T_{\mathrm{a}}$ & $0.177^{* *}$ & 0.099 & 1.000 & & & & & & & & & & & & \\
\hline $\mathrm{RH}$ & -0.109 & $-0.899^{* *}$ & -0.019 & 1.000 & & & & & & & & & & & \\
\hline$R_{\mathrm{n}}$ & $-0.512^{* *}$ & 0.037 & $0.203^{* *}$ & -0.012 & 1.000 & & & & & & & & & & \\
\hline$P_{\mathrm{a}}$ & $-0.139^{*}$ & 0.043 & -0.090 & $-0.165^{*}$ & -0.039 & 1.000 & & & & & & & & & \\
\hline$P$ & -0.055 & $-0.356^{* *}$ & 0.108 & $0.394^{* *}$ & $0.169^{* *}$ & $-0.169^{* * *}$ & 1.000 & & & & & & & & \\
\hline $\mathrm{SWC}_{5}$ & $-0.049^{*}$ & $-0.542^{* *}$ & -0.045 & $0.600^{* *}$ & $-0.120^{*}$ & $-0.141^{* *}$ & $0.155^{* *}$ & 1.000 & & & & & & & \\
\hline $\mathrm{SWC}_{10}$ & 0.028 & $-0.307^{* *}$ & 0.077 & $0.383^{* *}$ & -0.004 & $-0.257^{* *}$ & -0.044 & $0.751^{* * *}$ & 1.000 & & & & & & \\
\hline $\mathrm{SWC}_{20}$ & 0.084 & -0.079 & 0.072 & $0.151^{*}$ & -0.005 & $-0.153^{* * *}$ & -0.047 & $0.565^{* *}$ & $0.741^{* * *}$ & 1.000 & & & & & \\
\hline $\mathrm{SWC}_{50}$ & 0.122 & $-0.185^{*}$ & $0.470^{* *}$ & $0.292^{* *}$ & 0.107 & $-0.166^{* *}$ & 0.106 & $0.582^{* *}$ & $0.662^{* *}$ & $0.666^{* *}$ & 1.000 & & & & \\
\hline$T_{\mathrm{s} 5}$ & $0.173^{* * *}$ & -0.069 & $0.933^{* * *}$ & $0.189^{* *}$ & $0.259^{* *}$ & $-0.197^{* *}$ & $0.237^{* *}$ & 0.082 & $0.164^{* *}$ & $0.148^{* *}$ & $0.595^{* *}$ & 1.000 & & & \\
\hline$T_{\mathrm{s} 10}$ & $0.150^{*}$ & $-0.184^{* *}$ & $0.891^{* *}$ & $0.306^{* *}$ & $0.237^{* *}$ & $-0.201^{* *}$ & $0.280^{* *}$ & $0.192^{* *}$ & $0.241^{* * *}$ & $0.218^{* *}$ & $0.679^{* *}$ & $0.980^{* *}$ & 1.000 & & \\
\hline$T_{\mathrm{s} 20}$ & $0.119^{*}$ & $-0.320^{* *}$ & $0.794^{* * *}$ & $0.442^{* *}$ & $0.180^{* *}$ & $-0.171^{* *}$ & $0.265^{* *}$ & $0.365^{* *}$ & $0.375^{* *}$ & $0.296^{* *}$ & $0.778^{* *}$ & $0.901^{* *}$ & $0.962^{* *}$ & 1.000 & \\
\hline$T_{\mathrm{s} 50}$ & 0.091 & $-0.403^{* *}$ & $0.651^{*}$ & $0.514^{* *}$ & 0.067 & $-0.119^{* * *}$ & $0.141^{* *}$ & $0.530^{* *}$ & $0.514^{* *}$ & $0.342^{* *}$ & $0.792^{* *}$ & $0.744^{* *}$ & $0.831^{* *}$ & $0.942^{* *}$ & 1.000 \\
\hline
\end{tabular}

\subsubsection{Effects of biotic factors on $k_{\mathrm{c}}$}

Biomass directly reflects the conditions of a biological community, so we selected it as a biotic factor. The results showed that the biomass gradually increased in May, rapidly increased in June and July, and reached a peak in August (with a maximum of $505 \mathrm{~g} / \mathrm{m}^{2}$ ), and then began to decrease rapidly in September (Fig. 6).

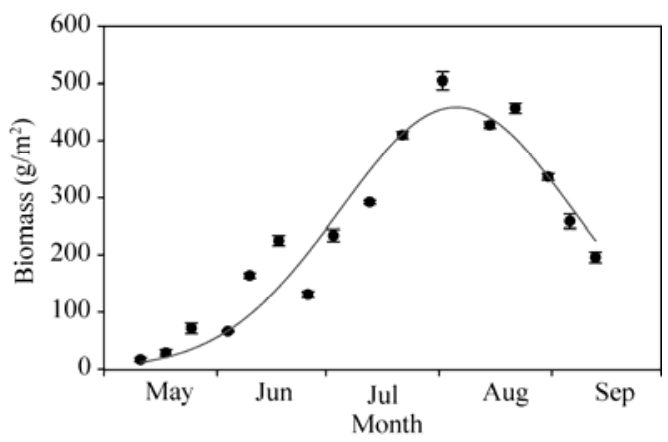

Fig. 6 Variation of biomass during the growing season in 2014. Bars indicate standard errors.

The regression analysis showed a significant positive correlation between biomass and $k_{\mathrm{c}}$ (Fig. 7). The linear regression equation is as follows:

$$
k_{\mathrm{c}}=0.0011 \times \text { biomass }+0.5687 \text {. }
$$

Considering both meteorological and biotic factors, we calculated daily $\mathrm{ET}_{\mathrm{cmod} 2}$ as follows:

$$
\begin{aligned}
\mathrm{ET}_{\mathrm{cmod} 2}= & \left(0.650+0.224 u-0.038 T_{\mathrm{a}}-0.030 R_{\mathrm{n}}-0.002 P+0.570 \mathrm{SWC}_{5}+0.110 T_{\mathrm{s} 5}-0.016 T_{\mathrm{s} 0}-\right. \\
& \left.0.009 T_{\mathrm{s} 20}\right) \times(0.0011 \times \text { biomass }+0.5687) \times \mathrm{ET}_{0},
\end{aligned}
$$

where $\mathrm{ET}_{\mathrm{cmod} 2}$ is the $\mathrm{ET}_{\mathrm{c}}$ calculated by Equation 13 .

\subsection{Testing estimated $\mathbf{E C}_{\mathrm{c}}$}

We validated Equations $11\left(\mathrm{ET}_{\mathrm{cmod} 1}\right)$ and $13\left(\mathrm{ET}_{\mathrm{cmod} 2}\right)$ using the $\mathrm{EC}$ system data collected during the growing seasons in 2015 and 2016. The estimated values were close to the observed values (Fig. 8). The slope, $R^{2}$ and IA of $\mathrm{ET}_{\mathrm{cmod} 2}$ were greater than those of $\mathrm{ET}_{\mathrm{cmod} 1}$ (Table 3), implying that the correlation between observed values and simulated values by $\mathrm{ET}_{\mathrm{cmod} 2}$ is better than that by 


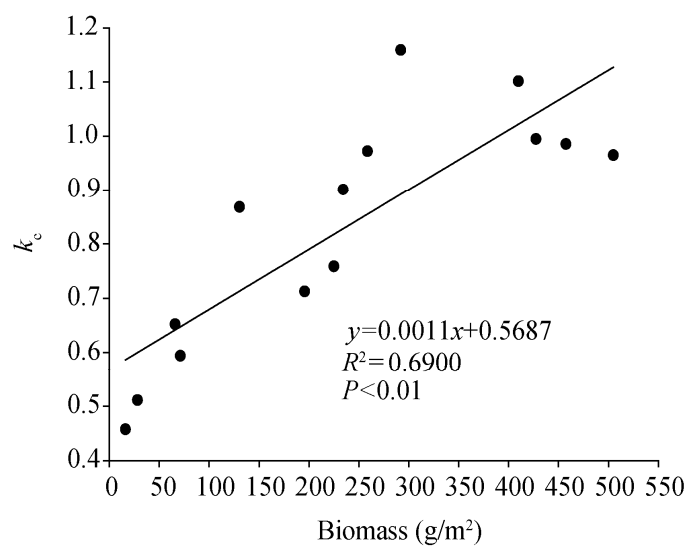

Fig. 7 Scatter plot between crop coefficient $\left(k_{\mathrm{c}}\right)$ and biomass

$\mathrm{ET}_{\mathrm{cmod} 1}$. The RRMSE obtained by $\mathrm{ET}_{\mathrm{cmod} 2}$ was smaller than that by $\mathrm{ET}_{\mathrm{cmod} 1}$, suggesting a higher accuracy of $\mathrm{ET}_{\mathrm{cmod} 2}$ than that of $\mathrm{ET}_{\mathrm{cmod} 1}$. The values of $\mathrm{CD}$ for both $\mathrm{ET}_{\mathrm{cmod} 1}$ and $\mathrm{ET}_{\mathrm{cmod} 2}$ were greater than 0.8 , indicating both regression equations are good. Overall, the performance of $\mathrm{ET}_{\mathrm{cmod} 2}$ that used both meteorological and biotic factors is better than that of $\mathrm{ET}_{\mathrm{cmod} 1}$ (only meteorological factors).
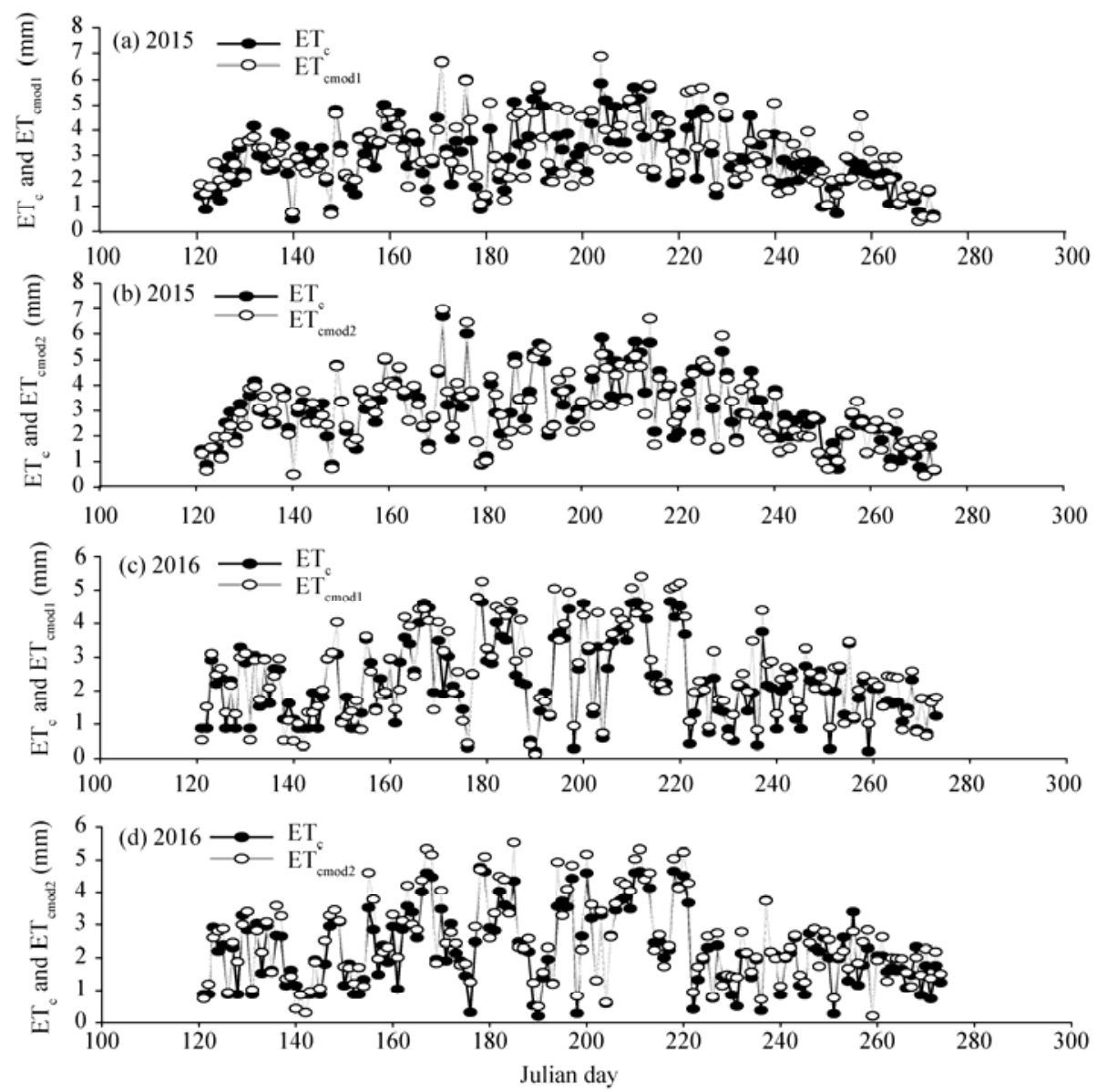

Fig. 8 Temporal variations of measured ET (ET $)$ and simulated $E T\left(\mathrm{ET}_{\mathrm{cmod}}\right)$. (a) $\mathrm{ET}_{\mathrm{c}}$ and $\mathrm{ET}_{\mathrm{cmod}}$ in 2015; (b) $\mathrm{ET}_{\mathrm{c}}$ and $\mathrm{ET}_{\mathrm{cmod} 2}$ in 2015; (c) $\mathrm{ET}_{\mathrm{c}}$ and $\mathrm{ET}_{\mathrm{cmod} 1}$ in 2016; and (d) $\mathrm{ET}_{\mathrm{c}}$ and $\mathrm{ET}_{\mathrm{cmod} 2}$ in 2016. 
Table 3 Summary of the parameters to assessing the accuracy of the two models

\begin{tabular}{|c|c|c|c|c|c|c|c|c|c|c|}
\hline \multirow{2}{*}{ Variable } & \multicolumn{2}{|c|}{ Slope } & \multicolumn{2}{|c|}{$R^{2}$} & \multicolumn{2}{|c|}{ RRMSE } & \multicolumn{2}{|c|}{ IA } & \multicolumn{2}{|c|}{$\mathrm{CD}$} \\
\hline & 2015 & 2016 & 2015 & 2016 & 2015 & 2016 & 2015 & 2016 & 2015 & 2016 \\
\hline $\mathrm{ET}_{\mathrm{cmod} 1}$ & 0.875 & 0.835 & 0.709 & 0.867 & 0.077 & 0.102 & 0.930 & 0.874 & 1.002 & 0.812 \\
\hline $\mathrm{ET}_{\mathrm{cmod} 2}$ & 0.921 & 0.890 & 0.866 & 0.906 & 0.050 & 0.092 & 0.972 & 0.916 & 0.942 & 0.835 \\
\hline
\end{tabular}

Note: $R^{2}$, correlation coefficient; RRMSE, Relative Root-Mean-Squared Error; IA, Index of Agreement; CD, Coefficient of Determination.

\section{Discussion}

\subsection{Variations of $\mathbf{E T}_{0}, \mathrm{ET}_{\mathrm{c}}$ and $P$}

The result shows that $\mathrm{ET}_{\mathrm{c}}$ was lower than $\mathrm{ET}_{0}$. The maximum of $\mathrm{ET}_{0}$ appeared in August, and the minimum was in December. However, the maximum of $\mathrm{ET}_{\mathrm{c}}$ appeared in July and the minimum occurred in December.

According to Equation 2, the meteorological and soil factors were the only factors that affected $\mathrm{ET}_{0}$. However, the $\mathrm{ET}_{\mathrm{c}}$ was affected not only by meteorological factors but also by biotic factors such as biomass, when $R_{\mathrm{s}}, R_{\mathrm{n}}, T_{\mathrm{a}}$, and $\mathrm{RH}$ increased from April and reached the peak values in August and then declined (Figs. 2 and 3). ET $_{\mathrm{c}}$ began to increase in April and reached the maximum in July with the canopy development during the growing season.

The annual ratio of $\mathrm{ET}_{\mathrm{c}}$ to $P$ (i.e., 1.067) indicates that $P$ was less than $\mathrm{ET}_{\mathrm{c}}$ (Hou et al., 2011). However, the ratio of $\mathrm{ET}_{\mathrm{c}}$ to $P$ during the growing season (from May to September) was 0.818 . This suggests that adequate water availability supports the plant growth in this period. The value of $\mathrm{ET}_{0}$ during the growing season was $666 \mathrm{~mm}$, and the ratio of $\mathrm{ET}_{0}$ to $P$ during the growing season was 1.240. This result was similar to the researches in some grassland ecosystems (Wever et al., 2002; Li et al., 2005). However, our result was higher than a non-irrigated pasture (Sumner and Jacobs, 2005) and an alpine winter pasture (Li et al., 2014).

ET process is governed by energy exchange at the vegetation surface and is limited by the amount of energy available (Semalty et al., 2011). $\mathrm{ET}_{0}$ in our study area is caused by the climatic conditions. $R_{\mathrm{n}}$ in the study area was higher than that in the Qinghai-Tibetan Plateau grassland $(\mathrm{Gu}$ et al., 2008), so $\mathrm{ET}_{0}$ was higher than that reported by Li et al. (2014) who conducted their study in the Qinghai-Tibetan Plateau grassland. Apart from energy enhancing the $\mathrm{ET}_{0}$ in some extent, the high SWC and $P$ could offer water for the need of plants (Yang and Zhou, 2011; Simona and Rita, 2013; Li et al., 2014). High $T_{\mathrm{s}}$ may inspire plant activity and make plant absorb more water (Gao et al., 2015), while low RH may improve the water vapor exchange between the atmosphere and vegetation (Gao et al., 2015).

\subsection{Temporal variations of $\boldsymbol{k}_{\mathrm{c}}$}

$k_{\mathrm{c}}$ quickly increased from May to June, remained at a high level in July and August, and then declined in September. The range of $k_{\mathrm{c}}$ in the study $(0.45-1.16)$ was larger than that of $k_{\mathrm{c}}$ reported in FAO 56 (0.30-1.05) (Allen et al., 1998), and it was higher than that of $k_{\mathrm{c}}$ observed in an alpine winter pasture (0.30-0.92) (Li et al., 2014), in a typical steppe (0.32-0.68) (Miao et al., 2009) and in a temperate desert steppe of Inner Mongolia (0.02-0.50) (Yang and Zhou, 2011; Zhang et al., 2012). Our result indirectly showed that the subalpine meadows in the Qilian Mountains featured more adequate moisture and better plant growth conditions than the other semi-arid and arid grassland ecosystems.

\subsection{Factors impacting $\boldsymbol{k}_{\mathrm{c}}$}

The highest correlation between $k_{\mathrm{c}}$ and environmental factors suggested that $R_{\mathrm{n}}$ was the most important factor for determining $k_{\mathrm{c}}$. Similar findings have been reported for an alpine winter pasture (Li et al., 2014). The higher $R_{\mathrm{n}}$ made a significant contribution to the $k_{\mathrm{c}}$ (Gao et al., 2015). However, Yang and Zhou (2011) selected a temperate desert steppe as their study area, which water was a key environmental factor pointed out that SWC was the most important factor, and Hou (2010) stated temperature was the most important meteorological factor. These differences may result from the different environmental conditions of plant growth. 
In addition to meteorological factors, biotic factors can greatly affect $k_{\mathrm{c}}$ (Tyagi et al., 2000; Williams et al., 2003; De Medeiros et al., 2005; Li et al., 2014). Biomass directly reflects the conditions of a biological community, so we selected it as a biotic factor to estimate $k_{c}$.

Figure 9 shows that the EC calculated by both Equations 11 and 13 is underestimated in 2015 and 2016. FAO Penman-Monteith model performs well under the abundant water condition. The underestimation of $\mathrm{ET}_{0}$ and $\mathrm{ET}_{\mathrm{c}}$, in our study area is likely due to the erratic precipitation which is not sufficient to meet water requirement criteria of FAO Penman-Monteith model.
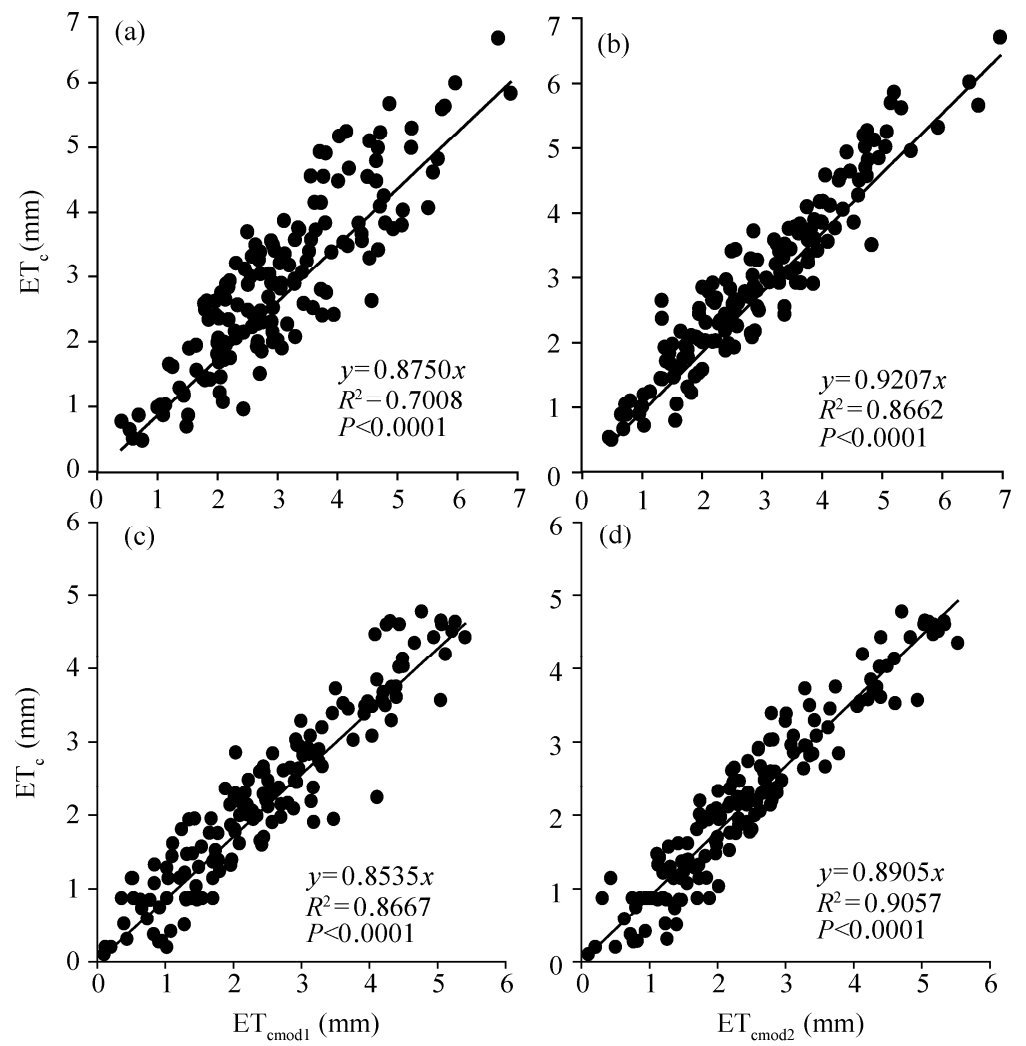

Fig. 9 Scatter plots between $\mathrm{ET}_{\mathrm{c}}$ and $\mathrm{ET}_{\text {cmod1 }}$ in 2015 (a), $\mathrm{ET}_{\mathrm{c}}$ and $\mathrm{ET}_{\text {cmod2 }}$ in 2015 (b), $\mathrm{ET}_{\mathrm{c}}$ and $\mathrm{ET}_{\mathrm{cmod1}}$ in 2016 (c), and $\mathrm{ET}_{\mathrm{c}}$ and $\mathrm{ET}_{\mathrm{cmod} 2}$ in 2016 (d)

\subsection{Testing estimated $\mathrm{EC}_{\mathrm{c}}$}

Equations $11\left(\mathrm{ET}_{\mathrm{cmod} 1}\right)$ and $13\left(\mathrm{ET}_{\mathrm{cmod} 2}\right)$ were validated using the $\mathrm{EC}$ system data collected during the growing season in 2015. The simulated accuracy by the Equations 11 and 13 was compared using slope, $R^{2}$, RRMSE, IA, and CD.

The values of RRMSE were smaller, and the results of the model correlation were better. In Table 3, the slope, $R^{2}$ and IA of $\mathrm{ET}_{\mathrm{cmod} 1}$ were greater and the RRMSE was smaller than those of $\mathrm{ET}_{\mathrm{cmod} 2}$, and the $\mathrm{CD}$ values of $\mathrm{ET}_{\mathrm{cmod} 1}$ and $\mathrm{ET}_{\mathrm{cmod} 2}$ were greater than 0.8 . The results indicate that the fitting method that comprehensively considers meteorological factors and vegetation conditions can be used to derive simulated $\mathrm{ET}_{\mathrm{c}}$ results that were closer to the actual observed $\mathrm{ET}_{\mathrm{c}}$ results.

\section{Conclusions}

The FAO Penman-Monteith model was used to simulate the $\mathrm{ET}_{0}$ over the subalpine meadows in the upper reaches of the Heihe River. Meanwhile, the ETc was measured by EC system. During the growing season, the ratio of $\mathrm{ET}_{\mathrm{c}}$ to $\mathrm{ET}_{0}$ is 0.663 , and the ratio of $\mathrm{ET}_{\mathrm{c}}$ to $P$ is 0.818 . Both ratios explained the habit of meadows in the study area is good. The $k_{\mathrm{c}}$ was used to estimate the $\mathrm{ET}_{\mathrm{c}}$. The average value of $k_{\mathrm{c}}$ during the growing season was 0.81 (ranging from 0.45 to 1.16). $R_{\mathrm{n}}, T_{\mathrm{a}}, u$, 
and $T_{\mathrm{s} 5}$ were the critical factors for controlling $k_{\mathrm{c}} . P_{\mathrm{a}}, \mathrm{SWC}_{5}, T_{\mathrm{s} 10}$ and $T_{\mathrm{s} 20}$ also showed a significant relation to $k_{\mathrm{c}}$. Finally, we developed a daily empirical $k_{\mathrm{c}}$ equation based on biomass, $T_{\mathrm{a}}, u$, $R_{\mathrm{n}}, P, \mathrm{SWC}_{5}, T_{\mathrm{s} 5}, T_{\mathrm{s} 10}$, and $T_{\mathrm{s} 20}$ to estimate the daily $k_{\mathrm{c}}$, and used the $k_{\mathrm{c}}$ and $\mathrm{ET}_{0}$ to estimate the $\mathrm{ET}_{\mathrm{c}}$. The model validation with 2015 and 2016 growing season data shows that the daily empirical $k_{\mathrm{c}}$ equation performed well in this study area.

\section{Acknowledgements}

This research was supported by the National Natural Science Foundation of China $(41571051,91425301)$. The authors would like to thank Dr. PENG Shouzhang and Dr. YUAN Liming for their help with setting up the EC system and weather station. Thanks to Gansu Qilianshan National Nature Reserve for their field assistance.

\section{References}

Alexandris S, Kerkides P. 2003. New empirical formula for hourly estimations of reference evapotranspiration. Agricultural Water Management, 60(3): 157-180.

Anderson D E, Verma S B, Rosenbuerg N J. 1984. Eddy correlation measurements of $\mathrm{CO}_{2}$, latent heat and sensible heat fluxes over a crop surface. Boundary-Layer Meteorology, 29: 263-272.

Allen R G, Smith M, Pereira L S, et al. 1994. An update for the calculation of reference evaporation. ICID Bulletin, 43(7): 672-674.

Allen R G, Pereira L S, Raes D, et al. 1998. Crop evapotranspiration guidelines for computing crop water requirements-FAO Irrigation and drainage paper 56. FAO, Rome.

Allen R G, Pereira L S, Howell T A, et al. 2011. Evapotranspiration information reporting: I. factors governing measurement accuracy. Agricultural Water Management, 98(6): 899-920.

ASCE-EWRI. 2005. The ASCE standardized reference evapotranspiration equation. In: Allen R G, Walter I A, Elliot R L, et al. Reported by the American Society of Civil Engineers (ASCE) Task Committee on Standardization of Reference Evapotranspiration. ASCE, Reston, 0-7844-0805-X, 204.

Aubinet M, Vesala T, Papale D. 2012. Eddy Covariance: A Practical Guide to Measurement and Data Analysis. Heidelberg: Springer, 365-376.

Burman D, Pochop L O. 1994. Evaporation, evapotranspiration and climatic data. Elsevier Science, 22: 1-5.

Cai J, Liu Y, Lei T, et al. 2007. Estimating reference evapotranspiration with the FAO Penman-Monteith equation using daily weather forecast messages. Agricultural and Forest Meteorology, 145(1-2): 22-35.

De Medeiros G A, Arruda F B, Sakai E. 2005. Crop coefficient for irrigated beans derived using three reference evaporation methods. Agricultural and Forest Meteorology, 135(1-4): 135-143.

Falge E, Baldocchi D, Olson R, et al. 2001. Gap filling strategies for defensible annual sums of net ecosystem exchange. Agricultural and Forest Meteorology, 107(1): 43-69.

Gao Y F, Zhao C Y, Peng S Z, et al. 2015. Evapotranspiration simulation of the grassland and sensitivity analysis in Tianlaochi catchment in the upper reaches of Heihe River. Journal of Desert Research, 35(5): 1338-1345. (in Chinese)

Gu J, Smith E A, Merritt J D. 1999. Testing energy balance closure with GOES-retrieved net radiation and in situ measured eddy correlation fluxes in BOREAS. Journal of Geophysical Research, 104(D22): 27881-27893.

Gu S Y, Tang X, Cui M, et al. 2008. Characterizing evapotranspriration over a meadow ecosystem on the Qinghai-Tibetan plateau. Journal of Geophysical Research, 113: 693-702.

Hou Q, Wang Y S, Yang Z L, et al. 2010. Analysis of control factors of crop coefficient in typical steppe. Chinese Journal of Grassland, 32: 58-64. (in Chinese)

Hou Q, Wang Y S, Shi G H, et al. 2011. Studies on crop coefficients of typical steppe in Inner Mongolia. Acta Prataculturae Sinica, 20(4): 34-41. (in Chinese)

Howell T A, Schneider A D, Jensen M E. 1991. History of lysimeter design and use for evapotranspiration measurements. Lysimeters for evapotranspiration \& environmental measurements: Proceedings of the International Symposium on Lysimetry. ASCE, Honolulu, HI, 1-9.

Jensen D, Hargreaves G, Temesgen B, et al. 1997. Computation of $\mathrm{ET}_{0}$ under nonideal conditions. Journal of Irrigation \& Drainage Engineering, 123(5): 394-400.

Jensen M E, Burman R D, Allen R G. 1990. Evapotranspiration and Irrigation Water Requirements. New York: American Society of Civil Engineers, 70-72.

Li J, Wang B, Liu X Q, et al. 2014. A study of fitting an alpine winter pasture evapotranspiration to a model based on the 
Penman-Monteith equation. Journal of Animal and Veterinary Advances, 13(3): 123-131.

Li S G, Lai C T, Lee G, et al. 2005. Evapotranspiration from a wet temperate grassland and its sensitivity to microenvironmental variables. Hydrological Processes, 19(2): 517-532.

Lockwood J G. 1999. Is potential evapotranspiration and its relationship with actual evapotranspiration sensitive to elevated atmospheric $\mathrm{CO}_{2}$ level? Climate Change, 41(2): 193-212.

Mahrt L. 1998. Flux sampling strategy for aircraft and tower observations. Journal of Atmospheric and Oceanic Technology, 15: 416-429.

Massman W J. 2000. A simple method for estimating frequency response corrections for eddy covariance systems. Agricultural and Forest Meteorology, 104(3): 185-198.

Mastrorilli M, Katerji N, Rana G, et al. 1998. Daily actual evapotranspiration measured with TDR technique in Mediterranean conditions. Agricultural and Forest Meteorology, 90(1-2): 81-89.

Mauder M, Foken T. 2004. Documentation and instruction manual of the eddy covariance software package TK2. Work Report University of Bayreuth, Department of Micrometeorology.

Miao H, Chen S, Chen J, et al. 2009. Cultivation and grazing altered evapotranspiration and dynamics in Inner Mongolia steppes. Agricultural and Forest Meteorology, 149(11): 1810-1819.

Mitchell P J, Veneklass E, Lambers H, et al. 2009. Partitioning of evapotranspiration in a semi-arid eucalypt woodland in south-western Australia. Agricultural and Forest Meteorology, 149(1): 25-37.

Molina H P M, Navarro A M, Osorio M C R, et al. 2006. Social and irrigation water management issues in some water user's associations of the Low Segura River Valley (Alicante, Spain). Sustainable Irrigation Management, Technologies and Policies, 96: 205.

Ohmura A. 1982. Objective criteria for rejecting data for Bowen ratio flux calculations. Journal of Applied Meteorology and Climatology, 21(4): 595-598.

Papale D, Reichstein M, Aubinet M, et al. 2006. Towards a standardized processing of net ecosystem exchange measured with eddy covariance technique: algorithms and uncertainty estimation. Biogeosciences, 3: 571-583.

Reichstein M, Falge E, Baldocchi D, et al. 2005. On the separation of net ecosystem exchange into assimilation and ecosystem respiration: review and improved algorithm. Global Change Biology, 11(9): 1424-1439.

Semalty P D, Dev K, Kumar S, et al. 2011. Estimation of forest evapotranspiration over Uttarakhand hills, India. Indian Journal of Physics, 85: 1277-1285.

Simona C, Rita P. 2013. Corrected surface energy balance to measure and model the evapotranspiration of irrigated orange orchards in semi-arid Mediterranean conditions. Irrigation Science, 31(5): 1159-1171.

Song K C, Kang E S, Jin B W, et al. 2004. An experimental study of grassland evapotranspiration in the mountain watershed of the Heihe River Basin. Journal of Glaciology and Geocryology, 26(3): 349-356. (in Chinese)

Stannard D I, Blanford J H, Kustas W P, et al, 1994. Interpretation of surface flux measurements in heterogeneous terrain during the Monsoon '90 experiment. Water Resources Research, 30: 1227-1239.

Sumner D M, Jacobes J M. 2005. Utility of Penman-Monteith, Priestley-Taylor, reference evapotranspiration, and pan evaporation methods to estimate pasture evapotranspiration. Journal of Hydrology, 308(1-4): 81-104.

Sun X M, Zhu Z L, Wen X F, et al. 2006. The impact of averaging period on eddy fluxes observed at ChinaFLUX sites. Agricultural and Forest Meteorology, 137(3-4): 188-193.

Swinbank W C. 1951. The measurement of vertical transfer of heat and water vapour by eddies in the lower atmosphere. Journal of Meteorology, 8(3): 135-145.

Tyagi N K, Sharma D K, Luthra S K. 2000. Determination of evapotranspiration and crop coefficients of rice and sunflower with lysimeter. Agricultural Water Manage, 45(1): 41-54.

Veroustraete F, Verstraeten W W, Feyen J. 2008. Assessment of evapotranspiration and soil moisture content across different scales of observation. Sensors, 8(1): 70-117.

Wever L A, Flanagan L B, Carlson P J. 2002. Seasonal and interannual variation in evapotranspiration, energy balance and surface conductance in a northern temperate grassland. Agricultural and Forest Meteorology, 112(1): 31-49.

Williams L E, Phene C J, Grimes D W, et al. 2003. Water use of mature Thompson seedless grapevines in California. Irrigation Science, 22(1): 11-18.

Williams L E, Ayars J E. 2005. Grapevine water use and the crop coefficient are linear functions of the shaded area measured beneath the canopy. Agricultural and Forest Meteorology, 132(3-4): 201-211.

Wilson K, Goldstein A, Falge E, et al. 2002. Energy balance closure at FLUXNET sites. Agricultural and Forest Meteorology, 113(1-4): 223-243.

Yang F, Zhou G. 2011. Characteristics and modeling of evapotranspiration over a temperate desert steppe in Inner Mongolia, 
China. Journal of Hydrological, 396(1-2): 139-147.

Yang Y, Chen R, Han C, et al. 2013. Measurement and estimation of the summertime daily evapotranspiration on alpine meadow in the Qilian Mountains, northwest China. Environmental Earth Sciences, 68(8): 2253-2261.

Zhang F, Zhou G, Wang Y, et al. 2012. Evapotranspiration and crop coefficient for a temperate desert steppe ecosystem using eddy covariance in Inner Mongolia, China. Hydrological Processes, 26(3): 379-386.

Zhao L W, Zhao W Z. 2014. Evapotranspiration of an oasis-desert transition zone in the middle stream of Heihe River, Northwest China. Journal of Arid Land, 6(5): 529-539.

Zhou L, Zhou G. 2009. Measurement and modelling of evapotranspiration over a reed (Phragmites australis) marsh in Northeast China. Journal of Hydrology, 372(1-4): 41-47. 